УДК 342.951

DOI https://doi.org/10.32849/2663-5313/2020.6.18

В'ячеслав Абросъкін,

канд. юрид. наук, ректор

Одеського державного університету внутрішніх справ

\title{
МЕТА СТВОРЕННЯ ТА ПРИНЦИПИ ДІЯЛЬНОСТІ ЗАКЛАДІВ ВИЩОЇ ОСВІТИ МВС УКРАЇНИ ЯК СУБ'ЄКТІВ РЕАЛІЗАЦІЇ ОСВІТНЬОЇ ФУНКЦІЇ ДЕРЖАВИ
}

Дослідження присвячено таким важливим специфічним суб'єктам реалізації освітньої функиіі держави, як заклади вищої освіти Міністерства внутрішніх справ України. Виокремлено такі особливості відомчих ЗВО МВС України: профільна діяльність державних органів, для яких здійснюється підготовка кадрів, відбивається на змісті вищої освіти; умови (процедури) навчання у відомчих ЗВО є специфічними; структура керування діяльністю ЗВО є складною та дворівневою, в ній водночас задіяні МОН і МВС; процес активного реформування МОН, МВС та самих 3 ВО триває; існує велика кількість завдань та иілей, які учасники прочесу реформування ставлять одночасно.

Приймаючи до уваги особливості системи внутрішніх справ та спрямованість окремих ї органів, з'ясовано перелік цілей утворення відомчих закладів вищої освіти. Разом із тим уточнено зміст таких понять, як мета та завдання, визначено загальну мету створення ЗВО зі специфічними умовами навчання, що знаходяться в підпорядкуванні МВС України.

Приділено увагу приниипам, відповідно до яких здійснюється діяльність закладів вищої освіти МВС. Проаналізовано співвідношення приниипів із метою та завданнями зазначених навчальних закладів. 3 урахуванням иих особливостей узагальнено зміст поняття приниипів, наведена їх класифікація та стислий перелік. Обгрунтовано, що принципи діяльності ЗВО МВС України доцільно поділити на: такі, що за своєю спрямованістю збігаються з приниипами, закріпленими в керівних нормативних актах більш високого порядку; такі, що є спеціалізованими

Зроблено висновок про те, що мета та приниипи діяльності закладів вищої освіти МВС України $\epsilon$ одним із важливих, обов'язкових елементів їхнього адміністративно-правового статусу. Встановлено, що за своїм призначенням мета та приниипи діяльності закладів вищої освіти МВС України $\epsilon$ логічно і функціонально пов'язаними, взаємодоповнюючими один одного категоріями. Саме через иі поняття розкривається дійсна функиіональна спрямованість суб'єктів ЗВО МВС України. А формалізація змісту мети та принципів у відповідних нормативно-правових актах є показником якості регулювання сфери діяльності суб'єктів освітньої діяльності.

Ключові слова: мета, принципи, завдання, вища освіта, адміністративно-правовий статус, заклади вищої освіти, ЗВО, специфічні умови навчання, Міністерство внутрішніх справ України, MBC.

Постановка проблеми. Сьогодні кадри для Національної поліції України (НПУ), Національної гвардії України (НГУ), Державної прикордонної служби України (ДПСУ), Державної служби України 3 надзвичайних ситуацій (ДСНС), Державної міграційної служби України (ДМС) та безпосередньо для Міністерства внутрішніх справ України (МВС) готують заклади вищої освіти зі специфічними умовами навчання (далі - 3ВО). I хоча сутність діяльності перелічених органів, вочевидь відрізняється один від одного, проте робота зазначених ЗВО спрямовується Кабінетом Міністрів України лише через одного Міністра - Міністра внутрішніх справ. Саме він утворює, реорганізовує і ліквідує заклади (в тому числі вищої освіти), що належать до сфери управління МВС, (а також) затверджує їхні положення (статути) [1, п. 20 ч. 11].

Водночас головним органом у системі центральних органів виконавчої влади, що забезпечує формування та реалізує державну політику у сферах освіти і науки, а також забезпечує формування та реалізацію державної політики у сфері здійснення державного нагляду (контролю) за діяльністю закладів освіти, підприємств, установ та організацій, які надають послуги у сфері освіти або провадять іншу діяльність, пов'язану 3 наданням таких послуг, незалежно від їх підпорядкування і форми 
власності [2, ч. 1], є Міністерство освіти і науки України (МОН).

Таким чином, відомчі 3ВО зі специфічними умовами навчання, що належать до сфери управління МВС та центральних органів виконавчої влади (ЦОВВ), мають дворівневе підпорядкування. Але це не єдина їхня особливість. Зараз із процесами євроінтеграції в Україні відбуваються заходи з реформування, які привносять суттєві зміни в роботу обох міністерств та самих 3ВО. Наприклад, «Календарем реформи освіти і науки» до кінця 2020 року передбачене запровадження формульного підходу до розміщення державного замовлення для магістратури, а також запровадження єдиного вступного іспиту з іноземної мови для вступу до магістратури i єдиного фахового вступного іспиту до магістратури для спеціальностей 081 «Право» та 293 «Міжнародне право» [3, с. 5]. У свою чергу «Концепція реформування освіти в МВС України» пов’язує свої очікування від впровадження реформ із формуванням єдиної політики в галузі відомчої освіти, а також передбачає оптимізацію системи навчальних закладів тощо [4, розділ V].

Все викладене свідчить про такі особливості відомчих 3ВО: профільна діяльність державних органів, для яких здійснюється підготовка кадрів, відбивається на змісті вищої освіти; умови (процедури) навчання у відомчих ЗВО є специфічними; структура керування діяльністю ЗВО є складною та дворівневою, в ній водночас задіяні МОН і МВС; процес активного реформування $\mathrm{MOH}, \mathrm{MBC}$ та самих 3ВО триває; існує велика кількість завдань та цілей, які учасники процесу реформування ставлять одночасно.

Тож, постає питання управління переліченими особливостями та координації виконання численних завдань, а також їх нормативно-правового регулювання, причому якість цих дій бажано оцінити ще до завершення реформування. На нашу думку, ефективними засобами, придатними для виконання цього завдання, є дослідження і формалізація мети та принципів діяльності 3ВО МBC

Дослідженнями питань вищої освіти займалось багато науковців. Зокрема, мету та принципи здійснення освітньої функції держави розглядали не лише юристи, але вчені в галузі державного управління та менеджменту, економіки, педагогіки, соціології й політології, філософії та історії тощо.

Серед дослідників-адміністративістів реформуванню діяльності закладів вищої освіти зі специфічними умовами навчання, підпорядкованими МВС, свою увагу приділили такі провідні вчені, як: В. Авер'янов,
О. Бандурка, О. Безпалова, Ю. Битяк, H. Губерська, О. Джафарова, С Дубровіна, Т. Коломоєць, В. Колпаков, А. Комзюк, О. Кузьменко, М. Легенький, І. Литвин, С. Мандрика, О. Миколенко, Т. Мінка, В. Олефір, В. Пальчикова, Д. Приймаченко, І. Савельєва, О. Сезонова, А. Селіванов, Ю. Фролов, І. Хомишин, Р. Шаповал, С. Шатрава, Ю. Шемшученко та ін.

Проте адміністративно-правові аспекти, що стосуються саме мети створення закладів вищої освіти МВС України та принципів їхньої діяльності, наразі досліджені недостатньо. Окрім того, слід зважати на те, що нормативно-правову базу за останні роки було суттєво переглянуто та реформовано. Система суб'єктів реалізації освітньої функції держави, які знаходяться в підпорядкуванні в МВС України, також зазнала змін, чим і зумовлюється актуальність дослідження.

Мета статті. Необхідно наголосити, що вибір принципів та формулювання мети безпосередньо впливають на якість здійснення 3ВО МВС своїх освітніх функцій. Тож, адміністративно-правова оцінка їхнього сучасного стану є метою цього дослідження.

Задачами дослідження $є$ : уточнення змісту таких понять, як: мета, цілі, завдання та принципи; аналіз їх взаємозв'язку, співвідношення та вираження відносно освітньої діяльності ЗВО МВС України; узагальнення та класифікація зазначених понять.

Виклад основного матеріалу. Дослідження варто розпочати 3 аналізу походження та розгляду значення, яке має категорія «мета». У перекладі 3 латини «meta» означає стан у майбутньому, котрий можливо змінити відносно теперішнього та варто, бажано або необхідно досягнути [5]. Словник української мови визначає «мету» як те, до чого хтось прагне, чого хоче досягти та певним чином ототожнює мету з поняттям «ціль» [6, ст. 683]. Філософський енциклопедичний словник вкладає в поняття мети усвідомлене передбачення бажаного результату діяльності, яке зумовлює пошук засобів і шляхів його досягнення [7, с. 371]. Поняття ж «ціль» словник розкриває як ідеальний образ майбутнього, бажаного результату людської діяльності [7, с. 712]. Психологічний словник розглядає мету як суб'єктивний образ бажаного результату очікуваної діяльності або дії. I наголошує, що мета має винятково важливе значення для спрямування, організації діяльності, постановки конкретних завдань [8, с. 159]. Водночас термін «ціль» словник тлумачить як ідеальний, бажаний результат діяльності і поведінки людини, що породжу- 
ється свідомістю і детермінує сам процес його досягнення [8, с. 327].

Наведені визначення дозволяють стверджувати, що категорії «мета» та «ціль» перетинаються і в певному сенсі можуть бути синонімами. Окрім того, зазначені формулювання дають підстави виділити спільні для більшості значень характеристики.

У галузі юридичних наук таку спробу зробив, наприклад, Д. Приймаченко, який виділив ознаки, що характеризують категорію «мета», а саме: 1) мета відіграє роль рушійної сили, яка спонукає до діяльності; 2) $є$ не тільки каталізатором діяльності, а й фактором, що існує та впливає на весь хід діяльності; 3) мета активно впливає на організацію та структуру діяльності; 4) спонукає до пошуку найбільш оптимальних засобів та способів діяльності; 5) виконує функцію керівних засад, що упорядковують та регулюють діяльність [9, с. 91].

Деякі науковці вважають підхід, використаний Д. Приймаченком, більш управлінським, ані юридичним. Погоджуючись із такою характеристикою, надамо власне визначення терміна «мета», яке дозволить більш зручно проводити аналіз нормативноправових актів для їх розгляду в площині адміністративного права.

Тож, під метою ми розуміємо формалізований на рівні нормативно-правового документу опис головних рис бажаного результату діяльності суб'єкту правових відносин або основної функції чи призначення суспільного (державного, громадського) процесу. Для перевірки цього визначення проаналізуємо приклади закріплення мети в нормативно-правових документах.

Так, на законодавчому рівні можна знайти визначення мети державної регіональної політики, яка тлумачиться законодавцем як створення умов для динамічного, збалансованого розвитку України та іï регіонів, забезпечення їхньої соціальної та економічної єдності, підвищення рівня життя населення, додержання гарантованих державою соціальних стандартів для кожного громадянина незалежно від його місця проживання [10, ст. 2]. Закон України «Про правовий режим надзвичайного стану» містить визначення мети введення надзвичайного стану [11, ст. 2]. Закон України «Про правовий режим воєнного стану» (який втратив чинність), відповідно, визначав мету введення воєнного стану [12, ст. 2].

На рівні підзаконних нормативних актів закріплені такі терміни: «мета бюджетної програми» [13], «мета управління ризиками» [14] тощо. Цікавим є термін «місія (головна мета діяльності) органу виконавчої влади», під яким розуміється призначення органу для вирішення проблем суспільства (соціальних, економічних, гуманітарних та інших) [15].

Наведені факти наштовхують нас на ряд висновків. По-перше, запропоноване нами визначення терміна «мета» можна використовувати для аналізу нормативно-правових документів. По-друге, мета як категорія має свою ієрархічну структуру, подібну до структури законодавчих та нормативно-правових актів, але не ідентичну до неї, про що свідчить зміст терміна «місія», наданий на підзаконному рівні. По-третє, більшість законів, положень та навіть статутів не мають формально закріпленого визначення мети, притаманної суб'єкту або процесу (функції), яким вони присвячені. Що не протирічить наданому нами визначенню але зумовлює необхідність розгляду супутніх до «мети» категорій і розкриття їхньої сутності.

Оскільки мета не здатна охопити детальний опис бажаного результату та не дає прямої відповіді на те, як його досягнути, то виникає потреба в розгляді окремих кроків (сегментів), спрямованих на іï досягнення. Такими кроками є завдання, зазначені у відповідних нормативно-правових документах. Причому вони часто не потребують послідовного виконання і мають реалізовуватись одночасно. Виконання завдань у свою чергу пов'язано з необхідністю надання певних повноважень, які і закріплюються в нормативно-правових актах.

Отже, досліджуючи мету певного суб'єкта або процесу, необхідно проаналізувати закони та підзаконні нормативні акти, що стосуються окресленого питання. А у випадку відсутності в них чітко сформульованої мети вивести ії зміст із завдань, повноважень, інших даних, закріплених у підданих аналізу нормативних документах.

Такий підхід здається дещо інструментальним, що доцільно, коли потрібно ретельно розглянути існуючу ситуацію, але створює незручності, якщо чинні норми не задовольняють актуальних потреб суспільства. В останньому випадку корисним буде розширювати коло досліджуваних документів, включаючи в нього концепції, стратегії, конвенції, дослідження та інші документи, що торкаються питання.

Обгрунтувавши, таким чином, хід нашого дослідження, ми можемо впритул приступити до аналізу мети створення закладів вищої освіти МВС України.

Спочатку розглянемо мету освіти як такої. Закон України «Про освіту» спрямовує мету освіти на «всебічний розвиток людини як особистості та найвищої цінності суспільства, <..> виховання відповідальних громадян, які здатні до свідомого суспільного 
вибору та спрямування своєї діяльності на користь іншим людям і суспільству, збагачення на цій основі < ..> потенціалу Українського народу, підвищення освітнього рівня громадян задля забезпечення сталого розвитку України та її європейського вибору» [16, абз. 2]. Водночас Закон окреслює межі своєї дії - регулює суспільні відносини, що виникають у процесі реалізації конституційного права людини на освіту [17, ст. 53].

Таким чином, освіта постає однією з важливих функцій держави, яка має на меті, з одного боку, задоволення прав людей і громадян України, а з іншого - забезпечення сталого розвитку країни.

Ці положення підтверджуються й аналізом «Національної стратегії розвитку освіти в Україні на період до 2021 року», метою якої $€$ підвищення доступності якісної, конкурентоспроможної освіти відповідно до вимог інноваційного сталого розвитку суспільства; забезпечення особистісного розвитку людини згідно з ії індивідуальними здібностями, потребами на основі навчання протягом життя [18, розділ III].

Разом із тим освітня функція держави не обмежується лише навчанням. Так, Закон України «Про вищу освіту», уточнюючи межі вищої освіти, розкриває мету наукової, науково-технічної, мистецької та інноваційної діяльності ЗВО. Під ними розуміється поглиблення професійних компетентностей, що сприяє створенню нового культурно-мистецького продукту [19, ч. 1 ст. 65].

Крім того, в цьому ж Законі закріплене визначення, надане вищому військовому навчальному закладу - закладу вищої освіти зі специфічними умовами навчання. У ньому розкривається мета ЗВО зі специфічними умовами навчання - здійснення підготовки курсантів (слухачів, студентів), ад’юнктів на певних рівнях вищої освіти для подальшої служби і задоволення потреб Міністерства внутрішніх справ України [19, п. 6 ч. 1 ст. 1 розділ I] та інших органів за текстом закону.

Ми вже звертали увагу на те, що ЗВО МВС утворюються Міністром внутрішніх справ України. У свою чергу діяльність Міністерства внутрішніх справ регламентована «Положенням про МВС України» [1, п. 20 ч. 11]. Прямого визначення мети цього органу в документі не зазначено. Проте мета його діяльності випливає з частини першої зазначеного документа і передбачає, зокрема, формування державної політики із: забезпечення охорони прав і свобод людини, підтримання публічної безпеки і порядку, надання поліцейських послуг; захисту державного кордону; забезпечення цивільного захисту; вирішення питань міграції тощо [1, ч. 1].
У пошуку більш чіткого визначення мети створення міністерством відомчих ЗВО доцільно розглянути «Концепцію реформування освіти в Міністерстві внутрішніх справ України», закріплену наказом МВС. Метою Концепції $€$ «визначення підходів до оптимізації мережі вищих навчальних закладів МВС, удосконалення освітнього процесу, забезпечення тісного взаємозв'язку науки і практики, максимальне сприяння вирішенню завдань модернізації підготовки кваліфікованого персоналу, який < ...> буде спроможний на високому професійному рівні захищати територіальну цілісність країни, їі кордони, права, свободи та інтереси громадян, протидіяти злочинності, забезпечувати публічну безпеку і порядок у державі [4, розділ III].

Загальна мета та цілі самих 3ВО MBC досить чітко визначені пунктами 1.1 та 1.3 «Положення про вищі навчальні заклади $\mathrm{MBC}$. Таким чином, загальна мета відомчих ЗВО - це забезпечення навчання, виховання та професійної підготовки осіб з урахуванням нормативних вимог у галузі вищої освіти для задоволення освітніх потреб особи, суспільства і держави, а також здійснення наукової і науково-технічної діяльності. Основна мета діяльності вищих навчальних закладів системи МВС полягає в забезпеченні умов, необхідних для отримання особою вищої освіти, підготовки фахівців для органів і підрозділів MBC, інших органів виконавчої влади, підприємств, установ та організацій України [20, п. 1.1; п. 1.3].

3 викладеного ми бачимо, що підзвітність відомчих ЗВО відразу і МОН, і МВС органічно поєднує цілі, порушені зазначеними органами. Проте загальні цілі утворення ЗВО МВС, вочевидь, можна деталізувати, звернувши увагу на специфіку окремих органів, для яких здійснюється підготовка фахівців. Із цього приводу цікавим є факт відсутності власного ЗВО у Державної міграційної служби України, задоволення кадрових потреб якої здійснюється з числа випускників ЗВО інших органів системи МВС. Водночас із тим аналіз статутів відомчих ЗВО чітко показує специфіку їхніх цілей. Наприклад, мета Національної академії Державної прикордонної служби України передбачає підготовку кадрів, спрямованих на охорону громадського порядку та безпеки, виконання завдань із посилення охорони Державного кордону України [21, п. 1.5]. Мета Львівського державного університету безпеки життєдіяльності, зазначена серед основних напрямів діяльності університету, спрямована на підготовку фахівців у сфері цивільного захисту [22, п. 1.4]. 
Розглянувши узгодженість, ієрархію та специфіку цілей ЗВО МВС, їх деталізацію через виконувані завдання, ми все ж таки маємо відмітити, що цієї інформації недостатньо для якісного аналізу діяльності відомчих ЗВО. За межами нашої уваги залишається таке важливе питання, як вибір шляхів та засобів досягнення поставлених цілей. Відповідь на нього знаходиться в сутності принципів, якими керуються відомчі ЗВО.

Наразі є багато наукових робот та літератури, в яких розглядається сутність категорії «принципи». Аналіз різних позицій щодо розуміння даної категорії свідчить, що науковці досить солідарні в його розумінні.

Принцип (лат. principium - початок, основа) - це твердження, яке сприймається як головне, важливе, суттєве, неодмінне або принаймні бажане. У науці принципи відображають ті суттєві характеристики, що відповідають за правильне функціонування системи, без яких вона не виконувала би свого призначення [23].

В юридичних науках існує визначення терміна «принципи права», під якими розуміють об'єктивно властиві праву відправні начала, незаперечні вимоги (позитивні зобов'язання), які ставляться до учасників суспільних відносин із метою гармонічного поєднання індивідуальних, групових і громадських інтересів [24].

Як слушно зазначає А. Шпак, відмінності щодо тлумачення категорії «принципи» стосуються лише вибору синонімів, за допомогою яких може бути додатково позначено назване поняття (вихідні теоретичні положення, основні, керівні засади (ідеї), загальні нормативно-керівні положення, загальноприйняті норми-ідеї, провідні засади, незаперечні вимоги) тощо [25, с. 39].

Підкреслюючи саме призначення принципів (дозволяють вибирати шлях, засіб, спосіб досягнення поставленої мети), ми пропонуємо розуміти під принципами нормативно-керівні положення, що не містять у собі вказівки до безпосереднього виконання конкретного завдання чи досягнення окремої мети та не є окремими нормативноправовими актами, але виступають незаперечними вимогами та мірилом якості процесу їх виконання.

Наукові погляди на структуру та класифікацію принципів вже не відрізняються такою одностайністю. Так, у літературі можна знайти розмежування таких категорій, як «принципи освіти», «принципи освітньої політики» та «принципи державної політики у сфері вищої освіти». Н. Губерська виділяє систему загальних та спеціальних принципів державної політики у сфері вищої освіти [26, с. 13], І. Литвин, досліджуючи відносини у сфері надання освітніх послуг, виділяє такі ж групи принципів [27, с. 200-201]. В. Савіщенко класифікує принципи за педагогічним, суспільно-політичним та аксіологічним критеріями [28, с. 13]. На основі праць Т. Титаренка можна виділити групи принципів формування державної регіональної політики у сфері вищої освіти та принципів їі реалізації [29, с. 137].

Інтерпретуючи погляди зазначених науковців, ми бачимо, що принципи піддаються групуванню за рівнем та широтою їх застосування. 3 цього можна зробити висновок, що принципи не є універсальними, та їх набори на різних рівнях формування і реалізації освітньої політики не мають бути ідентичними. Така особливість зумовлює проблему узгодженості принципів. Аби перевірити, чи виконується наше припущення, розглянемо принципи, на яких грунтується державна політика у сфері вищої освіти, та принципи, закріплені на рівні статутів відомчих ЗВО, тобто рівень, на якому безпосередньо реалізується освітня функція держави.

Частиною другою статті 3 Закону України «Про вищу освіту» закріплено 9 принципів державної політики, а саме принципи: 1) сприяння сталому розвитку суспільства; 2) доступності вищої освіти; 3) незалежності здобуття вищої освіти від політичних партій, громадських і релігійних організацій; 4) міжнародної інтеграції та інтеграції системи вищої освіти України у Європейській простір вищої освіти; 5) наступності процесу здобуття вищої освіти; 6) державної підтримки підготовки фахівців з вищою освітою для пріоритетних галузей економічної діяльності, напрямів фундаментальних і прикладних наукових досліджень, науково-педагогічної, мистецької та педагогічної діяльності; 7) державної підтримки освітньої, наукової, науково-технічної, мистецької та інноваційної діяльності університетів, академій, інститутів, коледжів; 8) сприяння здійсненню державно-приватного партнерства у сфері вищої освіти; 9) відкритості формування структури й обсягу освітньої та професійної підготовки фахівців з вищою освітою [19, ч. 2 ст. 3].

У свою чергу статути ЗВО МВС містять розділ, присвячений концепції освітньої діяльності. Група принципів, закріплена в цьому розділі статутів, здебільшого збігається для усіх ЗВО МВС.

До принципів освітньої діяльності відомчих $3 \mathrm{BO}$ [30, ч. 3 розділ II] відносяться: 1) гуманізм, демократизм, пріоритетність загальнолюдських цінностей; 2) автономія та самоврядування; 3) рівність умов для кожного здобувача вищої освіти в контексті 
повної реалізації його здібностей, таланту, всебічного розвитку; 4) нерозривність процесів навчання, науково-дослідної роботи і практичної діяльності; 5) використання стандартів вищої освіти як обов'язкового мінімуму змісту освіти та навчання; 6) ступенева підготовка фахівців; 7) багатопрофільність; 8) задоволення освітніх потреб осіб, які навчаються, відповідно до їхніх інтересів, здібностей та потреб суспільства, повної реалізації їхніх здібностей, таланту, всебічного розвитку; 8) якість освітніх послуг (якість змісту освіти, якість результатів освіти, якість технологій навчання); 9) інтенсифікація освітнього процесу завдяки заходам інноваційного розвитку освіти; 10) інтеграція до європейського та світового освітніх просторів; 11) моніторинг якості освіти, забезпечення його прозорості, сприяння громадському контролю; 12) академічна доброчесність.

Розглянувши обидві групи принципів, ми можемо помітити, що частина із них збігається.

Так, принцип міжнародної та європейської інтеграції притаманний обом групам і навіть сформульований майже ідентично.

Принцип наступності процесу здобуття вищої освіти перетинається із принципом ступеневої підготовки фахівців та в певному сенсі є його продовженням.

Принцип сприяння сталому розвитку суспільства знаходить своє відображення у принципі задоволення освітніх потреб (здобувачів освіти) та суспільства.

Доступність вищої освіти розкривається на рівні ЗВО як рівність умов для кожного здобувача вищої освіти в контексті повної реалізації його здібностей, таланту, всебічного розвитку.

Відкритість формування структури й обсягу освітньої та професійної підготовки фахівців з вищою освітою перекликається 3 принципом моніторингу якості освіти, забезпечення його прозорості, сприяння громадському контролю.

Інші вищеперелічені принципи не мають між собою тісного в'язку та спрямовані на регуляцію безпосередньої діяльності державного органу сфери освіти або ЗВО МВС. Проте цілком очевидно, що принципи, які би протирічили один одному, в цих групах відсутні. Аналогічна ситуація спостерігається і в разі порівняння принципів відомчих 3ВО 3 принципами, на яких діють органи системи МВС. Це дозволяє зробити нам висновок, що основою для класифікації принципів може слугувати їхня впорядкованість. Таким чином, принципи діяльності 3ВО МВС доцільно поділити на: такі, що за своєю спрямованістю збігаються 3 принципами, закріпленими в керівних нормативних актах більш високого порядку; та такі, що є спеціалізованими.

\section{Висновки}

Підводячи підсумки дослідження, варто зазначити, що за своїм призначенням мета та принципи діяльності закладів вищої освіти MBC України $€$ логічно і функціонально пов'язаними, взаємодоповнюючими один одного категоріями. Саме через ці поняття розкривається дійсна функціональна спрямованість суб'єктів ЗВО МВС. А формалізація змісту мети та принципів у відповідних нормативно-правових актах є показником якості регулювання сфери діяльності суб'єктів освітньої діяльності. У свою чергу мета та принципи є важливим елементом адміністративноправового статусу 3ВО МВС.

\section{Список використаних джерел:}

1. Про затвердження Положення про Міністерство внутрішніх справ України : Постанова Кабінету Міністрів України від 28.10.2015 р. № 878 Дата оновлення від: 30.08.2019 p. URL: https:// zakon.rada.gov.ua/laws/show/878-2015-п (дата звернення: 03.04.2020).

2. Про затвердження Положення про Міністерство освіти і науки України : Постанова Кабінету Міністрів України від 16.10.2014 р. № 630. Дата оновлення від: 01.01.2020 p. URL: https:// zakon.rada.gov.ua/laws/show/630-2014-п (дата звернення: 03.04.2020).

3. Урядовий портал «Реформа освіти та науки», «Календар реформи освіти і науки». URL: https://www.kmu.gov.ua/storage/app/media/ reforms/kalendar- reformi-osviti-i-nauki.pdf (дата звернення: 03.04.2020).

4. Про затвердження Концепції реформування освіти в Міністерстві внутрішніх справ України : Наказ Міністерства внутрішніх справ України від 25.11.2016 р. № 1252. Дата оновлення від: 28.02 .2017 p. URL: http://consultant. parus.ua/?doc=0AMQ2E07D1 （дата звернення: 03.04.2020).

5. Вікіпедія. Вільна енциклопедія, «Мета». URL: https://uk.wikipedia.org/ wiki/Мета (дата звернення: 03.04.2020)

6. Словник української мови (СУМ): у 11 т. Т. 4. (I-M) / АН Української РСР, Ін-т мовознав ім. О.О. Потебні ; редкол. : І.К. Білодід (голова) та ін. ; ред. тому: А.А. Бурячок, П.П. Доценко. Київ : Наук. думка, 1973. T. 4. (I-M). 840 c. URL: http:// sum.in.ua/s/meta (дата звернення: 03.04.2020).

7. Філософський енциклопедичний словник / НАНУ Ін-т філ. ім. Г.С. Сковороди ; редкол.: B.I. Шинкарук (голова) та ін. Київ : Абрис, 2002. 744 с. URL: http://shron1. chtyvo.org.ua/Shynkaruk Volodymyr/Filosofskyi entsyklopedychnyi_slovnyk.pdf (дата звернення: 03.04.2020) 
8. Психологічний словник / авт.-уклад. В.В. Синявський, О.П. Сергєєнкова ; ред. Н.А. Побірченко. Київ : Науковий світ, 2007. 274 c. URL: http://elibrary. kubg.edu.ua/id/ eprint/5980/3/O_Serhieienkova_IL.pdf (дата звернення: 03.04.2020).

9. Приймаченко Д.В. Митна політика держави та її реалізація митними органами : монографія. Дніпропетровськ : Академія митної служби України, 2006. 332 с. URL: http://biblio.umsf. dp.ua/jspui/bitstream/123456789/1949/1/ Приймаченко\%20Митна\%20політика\%20держави \%20 та\%201і\%20реалізація\%20митними\%20органами. pdf (дата звернення: 03.04.2020).

10. Про засади державної регіональної політики : Закон України від 05.02.2015 р. № 156VIII. Відомості Верховної Ради (ВВP). 2015. № 13 CT. 90. URL: https://zakon.rada.gov.ua/laws show/156-19 (дата звернення: 03.04.2020).

11. Про правовий режим надзвичайного стану : Закон України від 16.03.2000 р. № 1550-III. Вiдомості Верховної Ради України (ВВР). 2000. № 23. Ст. 176. Редакція від : 28.12.2015 p. URL: https:// zakon.rada.gov.ua/laws/show/1550-14 (дата звернення: 03.04.2020).

12. Про правовий режим воєнного стану: Закон України від 06.04.2000 р. № 1647-III. Відомості Верховної Ради Украӥни (ВВР). 2000. № 28. Ст. 224. Втратив чинність : 11.06 .2015 p. URL: https:// zakon.rada.gov.ua/laws/show/1647-14 (дата звернення: 03.04.2020).

13.Законодавство Украӥни, Термін «Мета бюджетної програми». URL: https://zakon. rada.gov.ua/laws/term/15186 (дата звернення: 03.04.2020).

14.Законодавство України, Термін «Мета управління ризиками». URL: https://zakon. rada.gov.ua/laws/term/15194 (дата звернення: 03.04.2020).

15.Законодавство Украӥни, Термін «Місія (головна мета діяльності) органу виконавчої влади». URL: https://zakon.rada.gov.ua/laws/ term/15728 (дата звернення: 03.04.2020).

16. Про освіту : Закон України від 05.09.2017 р. № 2145-VIII. Відомості Верховної Ради (ВВР). 2017. № 38-39. Ст. 380. Редакція від : 18.03.2020 p. URL: https://zakon.rada.gov.ua/laws/ show/2145-19\#Text (дата звернення: 03.04.2020).

17. Конституція України від 28.06.1996 р. Відомості Верховної Ради України (ВВР). 1996. № 30. Ст. 141 Редакція від : 01.01.2020 p. URL: https://zakon.rada.gov.ua/laws/show/254к/96вр\#top (дата звернення: 03.04.2020).

18. Про Національну стратегію розвитку освіти в Україні на період до 2021 року : Указ Президента України від 25.06.2013 р. № 344/2013. URL: https://zakon.rada.gov.ua/laws/ show/344/2013 (дата звернення: 03.04.2020).

19. Про вищу освіту : Закон України від 01.07.2014 р. № 1556-VII. Відомості Верховної Ради (ВВР). 2014. № 37-38. Ст. 2004. Редакція від : 18.03.2020 p. URL: https://zakon.rada.gov.ua/laws/ show/1556-18\#Text (дата звернення: 03.04.2020).
20. Про затвердження Положення про вищі навчальні заклади МВС : Наказ Міністерства внутрішніх справ України від 14.02.2008 р. № 62. Дата оновлення від : 30.04.2015 p. URL: https://zakon. rada.gov.ua/laws/show/z0193-08 (дата звернення: 03.04.2020)

21. Статут Національної академії Державної прикордонної служби України ім. Богдана Хмельницького : затверджено Наказом Адміністрації Державної служби України від 28.12.2017 р. № 121. URL: https://nadpsu.edu.ua/wp-content/ uploads/2019/03/statut-nadpsu.pdf (дата звернення: 03.04.2020)

22. Статут Львівського державного університету безпеки життєдіяльності (нова редакція) : затверджено Наказом Адміністрації Державної служби України 3 надзвичайних ситуацій від 23.08.2018 p. № 494. URL: https://ldubgd.edu.ua/ sites/default/files/statut_universitetu.pdf (дата звернення: 03.04.2020).

23. Вікіпедія. Вільна енциклопедія, «Принцип». URL: https://uk.wikipedia.org/ wiki/Принцип (дата звернення: 03.04.2020).

24. Вікіпедія. Вільна енциклопедія, «Принцип права». URL: https://uk.wikipedia.org/wiki/Принципи_права (дата звернення: 03.04.2020).

25. Шпак А.П. Адміністративно-правова охорона права інтелектуальної власності у сфері освіти : дис. ... канд. юрид. наук : 12.00.07. Київ, 2015. 210 c.

26. Губерська Н.Л. Адміністративні процедури у сфері вищої освіти : автореф. дис. ... на здобуття наук. ступеня доктора юрид. наук : 12.00 .07 «дміністративне право і процес; фінансове право; інформаційне право». Харків, 2016. 34 c. URL: http://nauka.nlu.edu.ua/download/ diss/Guberska/a_Guberska.pdf (дата звернення: 03.04.2020).

27. Литвин I.I. Адміністративно-правові відносини у сфері надання освітніх послуг : моногр. Харків : Панов, 2016. 428 с.

28. Савіщенко В.В. Організаційне та правове забезпечення освіти і науки в Україні : автореф. дис. ... на здобуття наук. ступеня доктора юрид. наук : 12.00.07 «Адміністративне право і процес; фінансове право; інформаційне право». Дніпро, 2016. 38 c. URL: https://dduvs.in.ua/wp-content/ uploads/files/Structure/science/rada/auto/9/3.pdf (дата звернення: 03.04.2020).

29. Титаренко Т.Б. Сутність та принципи формування регіональної політики розвитку ринку освітніх послуг в Україні. Економічний вісник НГУ. 2008. № 4. C. 134-138. URL: http://ir.nmu. org.ua/bitstream/handle/123456789/481/2008_4_ p134-138.pdf?sequence=1\&isAllowed=y (дата звернення: 03.04.2020).

30. Статут Харківського національного університету внутрішніх справ (нова редакція) : затверджено Наказом Міністерства внутрішніх справ України від 11.10.2019 р. № 857. URL: http://univd.edu.ua/files/generaldocs/ regulations.pdf?ver $=2019$ (дата звернення: 03.04.2020). 
Viacheslav Abroskin. Purpose of creation and principles of activity of higher education institutions of the Ministry of Internal Affairs of Ukraine as subjects of realization of educational function of the state

The research is devoted to such important specific subjects of realization of the educational function of the state as institutions of higher education of the Ministry of Internal Affairs of Ukraine. The following peculiarities of the Ministry of Internal Affairs of the Ministry of Internal Affairs of Ukraine are distinguished: the profile activities of state bodies for which training is carried out are reflected in the content of higher education; the conditions (procedures) of training in the departmental HEIs are specific; the structure of management of the ZVO activity is complex and two-tier; it simultaneously involves the MES and the Ministry of Internal Affairs; the process of active reform of the MES, the Ministry of Internal Affairs and the HEA itself is ongoing; there are many tasks and goals that participants in the reform process set at the same time.

Taking into account the peculiarities of the system of internal affairs and the orientation of its individual bodies, the list of goals for the establishment of departmental institutions of higher education has been clarified. At the same time, the content of such concepts as the purpose and the task was specified, the general purpose of creation of HEA with specific conditions of training, which are under the control of the Ministry of Internal Affairs of Ukraine, was defined.

Attention is paid to the principles according to which the activities of higher education institutions of the Ministry of Internal Affairs are carried out. The correlation of the principles with the purpose and tasks of these educational institutions is analyzed. Taking into account these peculiarities, the content of the concept of principles is summarized, their classification and a short list are given. It is substantiated that it is expedient to divide the principles of activity of the Ministry of Internal Affairs of Ukraine into: those which, in their orientation, coincide with the principles enshrined in higher regulatory acts; and those that are specialized

It is concluded that the purpose and principles of higher education institutions of the Ministry of Internal Affairs of Ukraine are one of the important, obligatory elements of their administrative and legal status. It is established that the purpose and principles of activity of higher education institutions of the Ministry of Internal Affairs of Ukraine are logically and functionally related, complementary categories. It is through these concepts that the real functional orientation of the subjects of the Defense Ministry of the Ministry of Internal Affairs of Ukraine is revealed. And formalizing the content of the purpose and principles in the relevant legal acts is an indicator of the quality of regulation of the sphere of activity of the subjects of educational activity.

Key words: purpose, principles, tasks, higher education, administrative and legal status, institutions of higher education, HEI, specific conditions of education, Ministry of Internal Affairs of Ukraine. 